\title{
Impact of Electronic Portfolios on Prospective Teachers' Participation, Motivation, and Autonomous Learning
}

\author{
Vanesa-María Gámiz-Sánchez, María-Jesús Gallego-Arrufat and \\ Emilio Crisol-Moya, University of Granada, Granada, Spain
}

\author{
vanesa@ugr.es; mgallego@ugr.es; ecrisol@ugr.es
}

\begin{abstract}
This study explores the impact of electronic portfolios on undergraduate learning in higher education. Based on a descriptive study, it analyses the prospective teacher's perception of use of these tools (electronic portfolio in Moodle-Mahara, in the institutional environment of a university in southern Europe), examining the variables participation, autonomous learning, and motivation. The results show no increase in motivation, but they do show an increase in autonomy, especially a progressive increase in the student's online participation in a blended learning context. The results show a positive correlation between the variables participation and university student's performance. Research into the uses and impact of electronic portfolios on undergraduates has implications for improving educational practice by fostering increased participation and autonomous learning.
\end{abstract}

Keywords: electronic portfolios, higher education, teacher preparation, autonomous learning, student motivations

\section{Introduction}

This study was developed by combining topics currently relevant in university teaching and learning, namely, the participation and motivation of students in online environments and autonomous learning. To address these key issues for improving university teaching, the investigation focuses on the application of information and communications technologies (ICTs) to teaching and learning - that is, on technology-enhanced learning in university institutions (Pollard \& Pollard, 2004; Price \& Kirkwood, 2014) and the gap between academic preparation and practice (Smith \& Greene, 2013). ICTs provide a series of tools that fulfil certain needs detected in teaching practice, such as lack of space and time for student work (individual and group) and for teaching tasks such as monitoring and tutoring students. These tools can increase students' active par-

(CC BY-NC 4.0) This article is licensed to you under a Creative Commons Attribution-

NonCommercial 4.0 International License. When you copy and redistribute this paper in full or in part, you need to provide proper attribution to it to ensure that others can later locate this work (and to ensure that others do not accuse you of plagiarism). You may (and we encourage you to) adapt, remix, transform, and build upon the material for any non-commercial purposes. This license does not permit you to use this material for commercial purposes. ticipation in the learning process and provide motivating experience that gives students freedom and flexibility to learn with greater autonomy (Jeffrey, Hegarty, Kelly, Penman, Coburn, \& McDonald, 2011; López-Fernández \& Rodríguez-Illera, 2009).

In seeking to enhance the student learning experience, this research studies a tool that has experienced a tremendous boom in recent decades: electronic portfolios (eportfolios, e-portfolios), also called online portfolios and, increasingly, digital portfolios (Blau, Mor, \&Neuthal, 2013). This tool 
was chosen because it focuses on student learning and is based primarily on the reflection, collaboration, and communication of students in their own learning.

The specific technology used here to improve learning is the electronic portfolio in the university (Von Konsky \& Oliver, 2012) in a blended-learning mode. Special attention is given to the student's perspective (Tosh, Light, Fleming, \& Haywood, 2005), in this case, the perspective of students in Teacher Education.

This article analyses the motivation and participation achieved by students in strategies that use technology to create environments that facilitate learning processes, specifically blended-learning environments (Graham, 2006). Research in this field has focused primarily on design of environments, perception and willingness of participants, and impact on learning outcomes (Halverson, Graham, Spring, Drysdale, \& Henrie, 2014). This study seeks to determine students' perceptions of motivation and participation in these environments, as well as the relationship of electronic portfolio use to academic performance.

\section{Literature Review}

\section{Electronic Portfolios as a Teaching and Learning Tool}

Change in university instruction will only be possible with methodologies that involve active participation of the student through his or her personal effort and work, and that motivate the student to make this effort. In tackling such methodological renewal, it is necessary to incorporate ICT use in both teaching and learning, integrating them in teaching methods, learning environments, and curriculum. The full potential of technologies and communication networks proposes new ways to develop the collaborative dimension of learning, new learning rhythms and tempos, and new ways of structuring information to construct knowledge (individual and collective).

This search for new methodologies and tools includes the electronic or digital portfolio. This portfolio is one of the ICT tools that focus on the student's learning processes when it is structured to engage students in reflective practice. It can also support the instructor's work.

The electronic portfolio is a transcript or dossier created and managed on the Internet, in which the student records his or her individual or group work, reflections, experiences, etc., for concurrent, interactive evaluation and response by the instructor. In their three major contributions to the field, Barrett (2007), Hartnell-Young and Morriss (2007) and Bahous (2008) identify the semantic field that defines the portfolio - on the one hand, its capability for design, organization, decision making, and assessment, and, on the other, its potential for collecting experiences, reflecting on them, and helping students to manage their learning. A search for definitions finds two main approaches to e-portfolio development, approaches that view the portfolio as workspace, and as a showcase and framework for developing e-portfolios (Barrett, 2010).

A more in-depth examination of the processes of learning and evaluation developed through electronic portfolios shows that the most important elements are communication, collaboration, and reflection. In fact, this tool might help students to articulate their learning through the process of reflection and communication it promotes. Whereas some studies of reflection are oriented to professionals in the fields of school counsellor and school psychology education (Wakimoto \& Lewis, 2014), most address pre-service education professionals (Boulton, 2014; Lopez-Fernandez \& Rodriguez-Illera, 2009; Tochon, 2012).

The new online training scenarios in current university classrooms develop these processes in a cycle that includes negotiation and comprehension of goals, planning, development and gathering of evidence, reflection on experience and learning, and drafting of a publication to communicate 
the process. The use of electronic portfolios seeks to achieve better guidance in learning and assessment of students' learning.

There are numerous empirical studies on the use of electronic portfolios in teaching and learning processes (Alexiou \& Paraskeva, 2010; Chang, Liang, Tseng, \& Tseng, 2014; Chang, Tseng, Liang, \& Chen, 2013), assessment (Gorbunovs, Kapenieks, \& Kudina, 2013; Wang, 2010) and orientation-guidance (Blackburn \& Hakel, 2006; Wakimoto \& Lewis, 2014).

\section{Electronic Portfolios in Teacher Education}

Most research on electronic portfolios focuses on portfolio use in tertiary education institutions in general. Because teacher education is the most advanced field studying portfolios, analyses often focus on use of these portfolios for the learning and development of pre-service teachers (Butler, 2006). This is an important topic in university education in general, but it is even more important for pre-service teachers, as it involves their impact not only on initial training but also on professional development (Wray, 2007). Explorations of the use of the electronic portfolio in teacher education stress its possibilities for development of competencies in technology. Along these lines, the portfolio provides a focus for development of e-learning skills, as it facilitates use of new technologies in compiling the portfolio (Spendlove \& Hopper, 2006). In addition to these studies, extensive research has analysed the use of the electronic portfolio in training future teachers (Boulton, 2014; Ntuli, Keengwe \& Kyei-Blankson, 2009; Ritzhaupt, Parker \& Ndoye, 2012; Tochon, 2012; Trent \& Shroff, 2013), and studies centre on the electronic portfolio as a learning tool in teacher education.

In the context of this research, the Faculty of Education and School of Education have both used the electronic portfolio successful in facilitating trainees' engagement with a creative 'design and technology' process. The electronic portfolio was found to serve primarily as a developmental tool for promoting creative continuity and sound, reflective design practice within a structured educational design challenge (Spendlove \& Hopper, 2006). Other studies highlight identity struggles that the participants faced in using an electronic portfolio to negotiate their own and others' professional identities in their teaching practicum placement schools (Trent \& Shroff, 2013).

\section{The Importance of University Students' Perspective}

In all of these studies of e-portfolio use in higher education, it is important to take into account the student's opinion and perspective. For example, self-regulated learning (SRL) has been studied in association with this technology (Abrami, Wade, Pillay, Aslan, Bures, \& Bentley, 2008), specifically the relationship between students' SRL ability and e-portfolio achievement in a language enhancement programme (Cheng \& Chau, 2013). In another attempt to understand the student's perspective, the study by Lopez-Fernandez and Rodriguez-Illera (2009) applied a mixed-method analysis to analyse the impact of this technological innovation on students and their satisfaction. The results show that the e-portfolio led to the students having positive opinions and feelings of self-efficacy when it was used as a tool to manage their learning and assessment during a semester, particularly after the second month of use. The students emphasized that the eportfolio was valuable as a personal developmental learning tool. Chen, Chang, Chen, Huang, and Chen (2012), on the other hand, argue that the utility users perceive in the electronic portfolio system influences their attitude and intention more than does perceived ease of use. Moreover, service quality utility has a greater influence on user satisfaction and intention than do system quality and information quality.

The foregoing research affirms that the student's perspective is important (Tosh et al., 2005), as is the knowledge construction that e-portfolios can facilitate (B. L. Cambridge, 2001; Chang et al., 2014). 


\section{The Impact of Electronic Portfolios on Learning in Communities and Personalized Learning}

Another important line of study is the impact of e-portfolio use at both community level (Blau et al., 2013) and individual level (Ballard \& Butler, 2011; Barrett \& Garrett, 2009). The five most basic functions identified are (1) storage, (2) information management, (3) connections, (4) communication, and (5) development, which include both personal and community use (Abrami \& Barrett, 2005; Barrett, 2007; Blau et al., 2013; D. Cambridge, Cambridge, \& Yancey, 2009; Jafari \& Kaufman, 2006).

In this respect, technology-mediated learning environments, specifically models based on blended-learning environments, offer great advantages, as they seem to increase student motivation (Ramakrisnan, Yahya, Hajar, Hasrol, \& Aziz, 2012). Using electronic portfolios helps students to reflect on their learning and to self-regulate the processes by which they can increase motivation (Akçil \&Arap, 2009).

As to participation, the student's role as active subject means greater participation and presence in all learning environments. Students who participate actively become involved in the process and obtain better results (Gámiz, Montes, \& Pérez, 2014).

\section{Methodology}

This study was performed during two academic years, 2012/2013 and 2013/2014, in different undergraduate courses in several degree programmes in the Faculty of Education at the University of Granada.

The methodological focus is descriptive. It uses quantitative and qualitative instruments to gather and analyse information in order both to describe the characteristics of the population in a more objective and verifiable way and to interpret qualitatively the perceptions and interpretations of the subjects who intervene in education-related activity (Colás \& Buendía, 1998).

The study goals are:

- To analyse electronic portfolios used in technology-mediated environments to foster students' active participation, autonomous learning, and motivation.

- To study undergraduates' perception of the use of these tools, taking into account above all their perceptions of participation, autonomous learning, and motivation.

- To analyse differences in perception of their work among students in different degree programmes, with the electronic portfolio in an institutional environment using MoodleMahara with a blended-learning mode.

- To analyse the relationship between the students' participation in their electronic portfolios and performance in the course.

Taking these objectives into account, the hypotheses are:

$\mathrm{H} 1$ : Using electronic portfolios in a technology-mediated teaching-learning process has a satisfactory influence on students, increasing their motivation, autonomy, and participation in the educational experience.

H2: There are significant differences between students' opinions of this educational strategy in the different degree programmes in the Faculty of Education at the University of Granada.

H3: Active participation of students in the work environment designed in the Moodle and Mahara platform is directly related to their performance in the course. 
The total number of students participating was 104, of whom 59 (the largest group) were pursuing an undergraduate degree in Primary Education (Group 1), 23 a degree in Social Education (Group 2) and 22 a degree in Early Childhood Education (Group 3) (Figure 1).

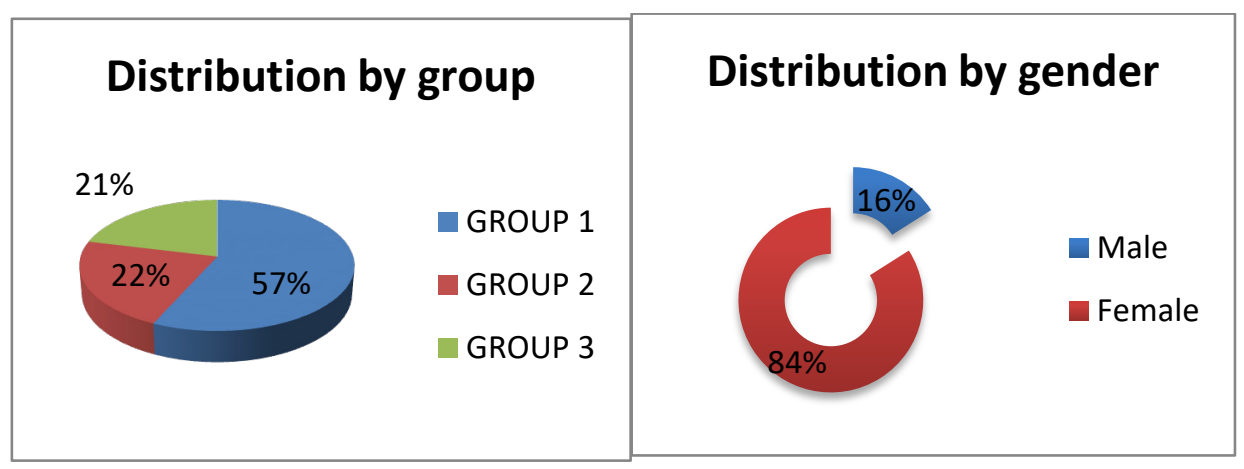

Figure 1.Distribution of the sample by group and gender

The age of the sample participants ranged from 19 to 54 years old. Most (70\%) were ages 19-22. As to gender (Figure 1), 84\% of the total study participants were women and $16 \%$ men, a proportion that follows the standard distribution of students studying Education.

The procedure followed in the study was a cyclical process divided into four stages: design, implementation, evaluation, and improvement. The design phase produced an electronic portfolio with a common base and methodology that was adapted to each course. (This was possible because the courses in each degree programme were very similar in content.) The technology chosen to implement the digital portfolio was Mahara, a tool specifically designed to create digital portfolios. This tool's ease of use, visual potential for web environments, and integration with Moodle suit this study especially well. In the evaluation stages, a questionnaire was constructed, to be described next. Finally, the improvement phase gave rise to a new portfolio design to be implemented and evaluated in successive stages using the platform.

The questionnaire used for gathering information had three dimensions: use of electronic portfolio as methodological strategy, professors' work, and usability of the portfolio through MoodleMahara. It was accompanied by a Likert-type scale from 1 to 5 ('Strongly disagree' to 'Strongly agree'). Various pilot tests were developed in similar contexts to validate the questionnaire. These, along with content validation performed by five experts and the contributions of pilot students, enabled development of the final version of the questionnaire.

The questionnaire's reliability was calculated using the Alpha Cronbach coefficient with the statistical programme SPSS 22.0.The global coefficient is $\mathrm{r}=0.939$ with a confidence level of $95 \%$ $(\mathrm{p} \leq 0.05)$. The first dimension ( 14 items) obtained a coefficient of $r=0.924$; the second dimension (9 items), $r=0.932$; and the third dimension ( 10 items), $r=0.924$. For a range of 0.600 as acceptable (Fox, 1987), the questionnaire developed is very reliable for all of the dimensions.

Qualitative results are obtained with an open questionnaire question on what elements students perceive should be kept and changed in using the electronic portfolio. Inductively and in accordance with the literature, the following categories were extracted from the data: General method, Moodle platform, Mahara platform, Contents, Infrastructure, Information, Portfolio design, Communication and collaboration, Platform organization, Evaluation, Method for posting activities, Theoretical classes, Feedback, Faculty, Group attitude.

A statistic provided by the Moodle platform was chosen to measure student activity and participation in the virtual environment: number of activities that the student performed on the platform 
(reading texts, forum messages, activities, etc.). Other studies have used this general statistic to measure students' overall participation (Gámiz et al., 2014).

The final grade earned in the course gives a measure of the student's performance on the course material. A specific percentage of this grade corresponds to assessment of work produced in the electronic portfolio, which counted for $50 \%-60 \%$ of the overall grade.

\section{Results}

The following presents the results obtained. They are divided into three sections, according to the three hypotheses proposed.

\section{Students' Perception of Electronic Portfolio Use}

First, the students' opinion of the mode of education used was analysed. Examination of the three dimensions in the questionnaire was divided to isolate student satisfaction with each of these topical areas and analyse each area separately.

For the first dimension, Figure 2 represents the students' average satisfaction with each of the items in the questionnaire related to the use of electronic portfolios as a methodological strategy. The figure shows the students' opinions about how the e-portfolio contributes in all of these aspects of learning, from nothing (1) to completely (5). The 3.7 average for general satisfaction shows that most students are quite satisfied with the methodology used.

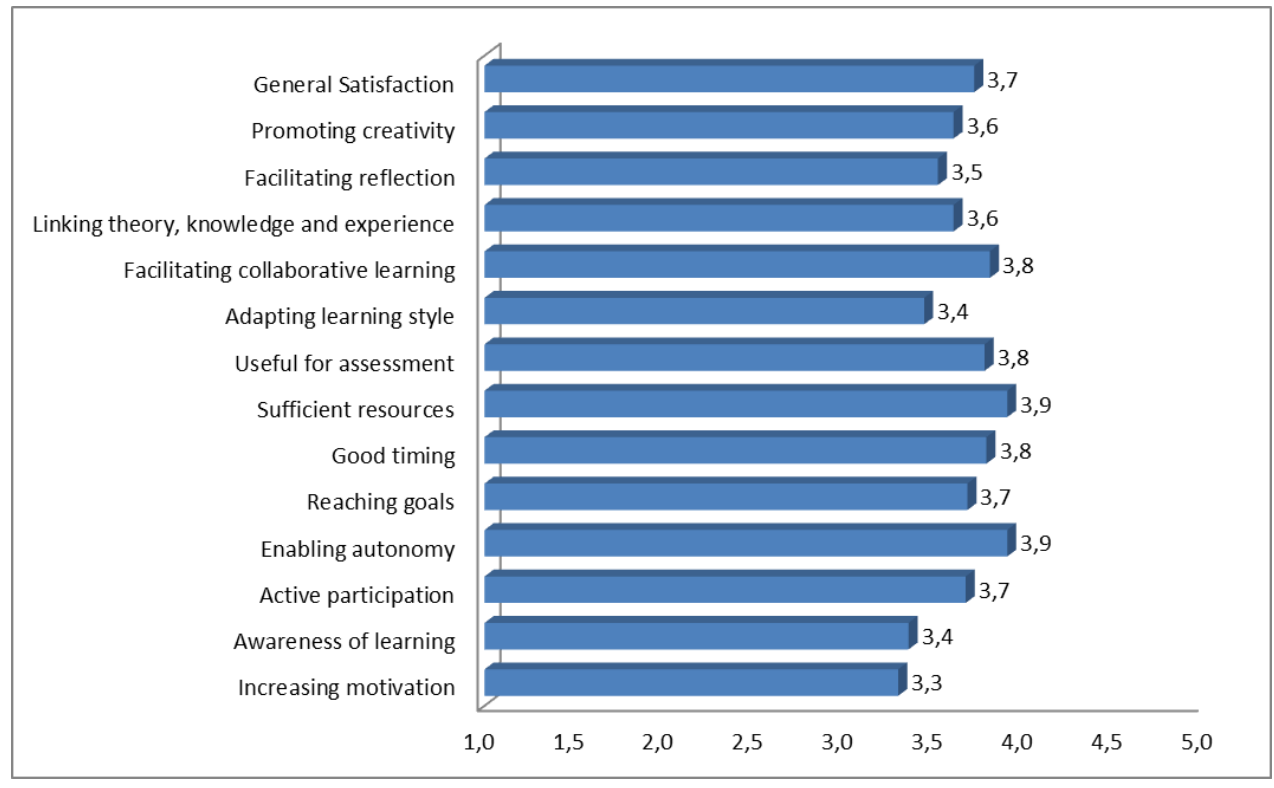

Figure 2. Students' opinion about Dimension 1:

Electronic portfolio as a methodological strategy

In all other items, the average of all indicators is greater than 3 (scale of 1-5), indicating that the students' evaluation was positive in all categories. The characteristics of the methodological strategy that received the highest score from students are autonomy in their education and learning, and resources that this environment provides (3.9). The next-highest characteristics are convenience of collaborative learning provided by the environment, utility of evaluation tool for the electronic portfolio, and appropriateness of the planning performed (3.8). Students also stress the active participation that this type of tool facilitates and its aid in achieving the learning goals established in the course (3.7). 
Among the items students ranked lowest, increase in motivation in the course due to this tool received the lowest average score (3.3). The categories with the next-lowest evaluation involved statements that this strategy helps to facilitate reflection and is adapted to each student's learning style (3.4).

Opinions on the dimension of professor's action are very positive, with averages above 4 and a general evaluation of 4.2 (Figure 3). These data reflect the students' perception of teachers' actions during the courses according to the items in the questionnaire.

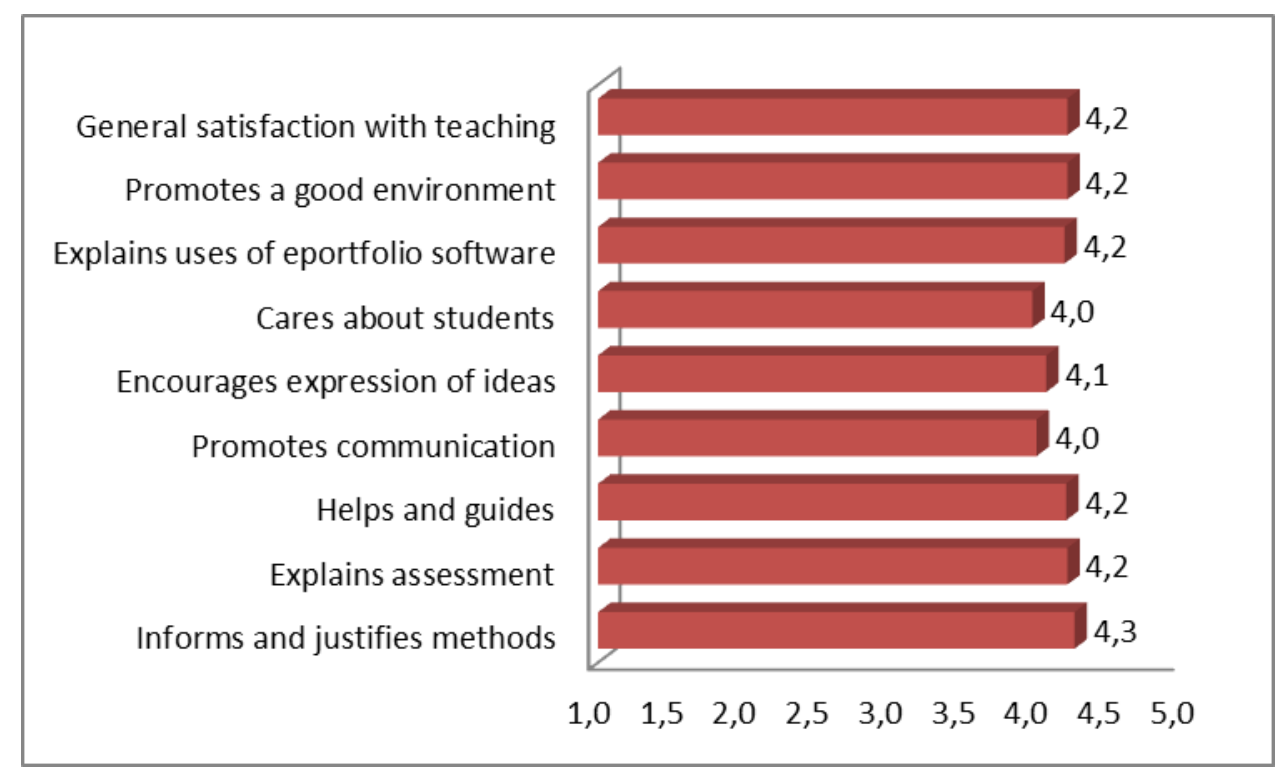

Figure 3. Students' opinion about Dimension 2: Teaching performance

The aspects with the highest scores are information about and explanation of the electronic portfolio (4.3). Professor's positive attitude to achieve good classroom atmosphere, explanation of the platform and help and orientation provided, and explanation of assessment receive the same score (4.2).

The students' perceptions of the platform's usability obtain an average above 3 . General satisfaction with the platform is 3.5 (Figure 4 ).

Most students agree (3.7) that they have sufficient technological knowledge to handle the platform and that it does not require more advanced technological knowledge than they already have. They stress the interaction tools (3.6) as factors shaping their positive opinion of the environment for collaborative learning and organization of the platform's contents (3.5). They also stress ease of using the platform and the need to invest more time than in other environments (3.4). The lowest-ranked item is the platform's help/support feature (3.1), which should perhaps be clearer and provide more explanation. 
Impact of E-Portfolios in Higher Education

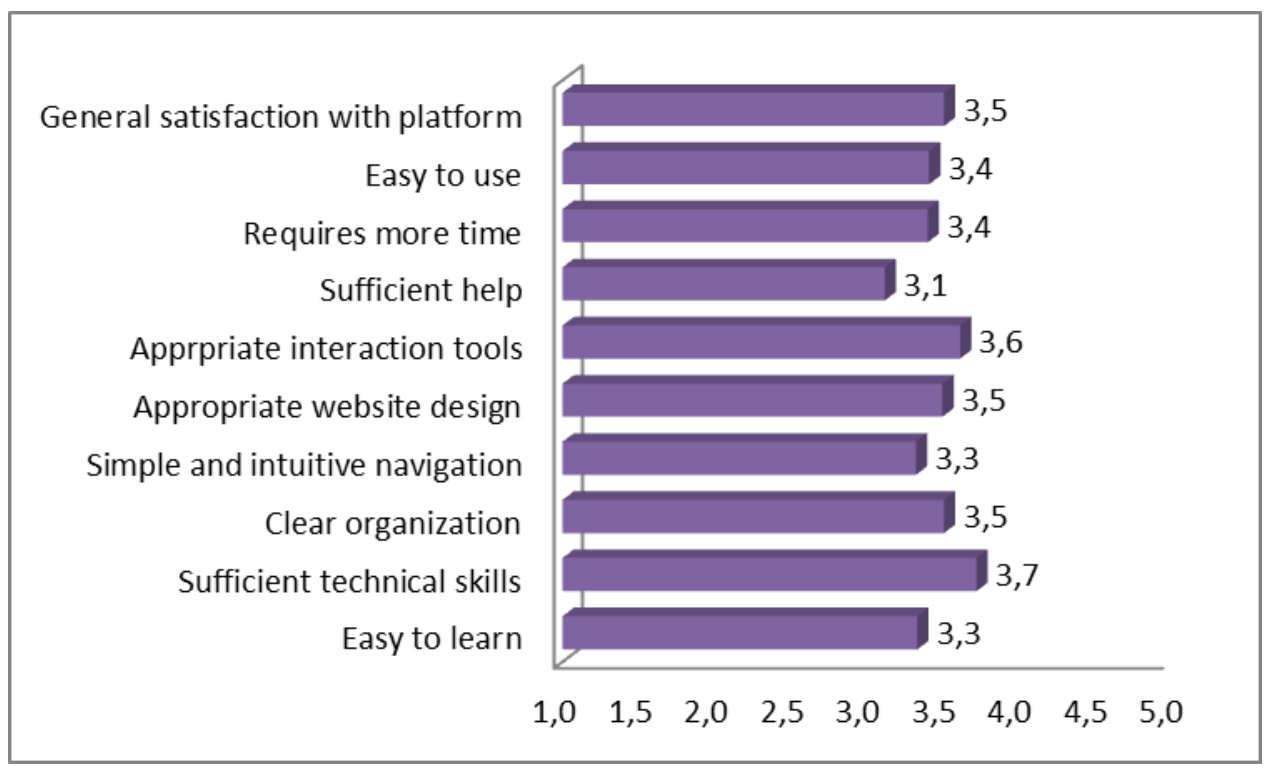

Figure 4. Students' opinion about Dimension 3: Usability of Moodle/Mahara

Content analysis of an open questionnaire question on 'Things that you would keep and change in the methodology used' was also performed. A total of 109 thematic units were analysed, of which 56 referred to students maintaining the methodology they experienced and 53 reflecting on things they would change. Figure 5 presents the frequency count.

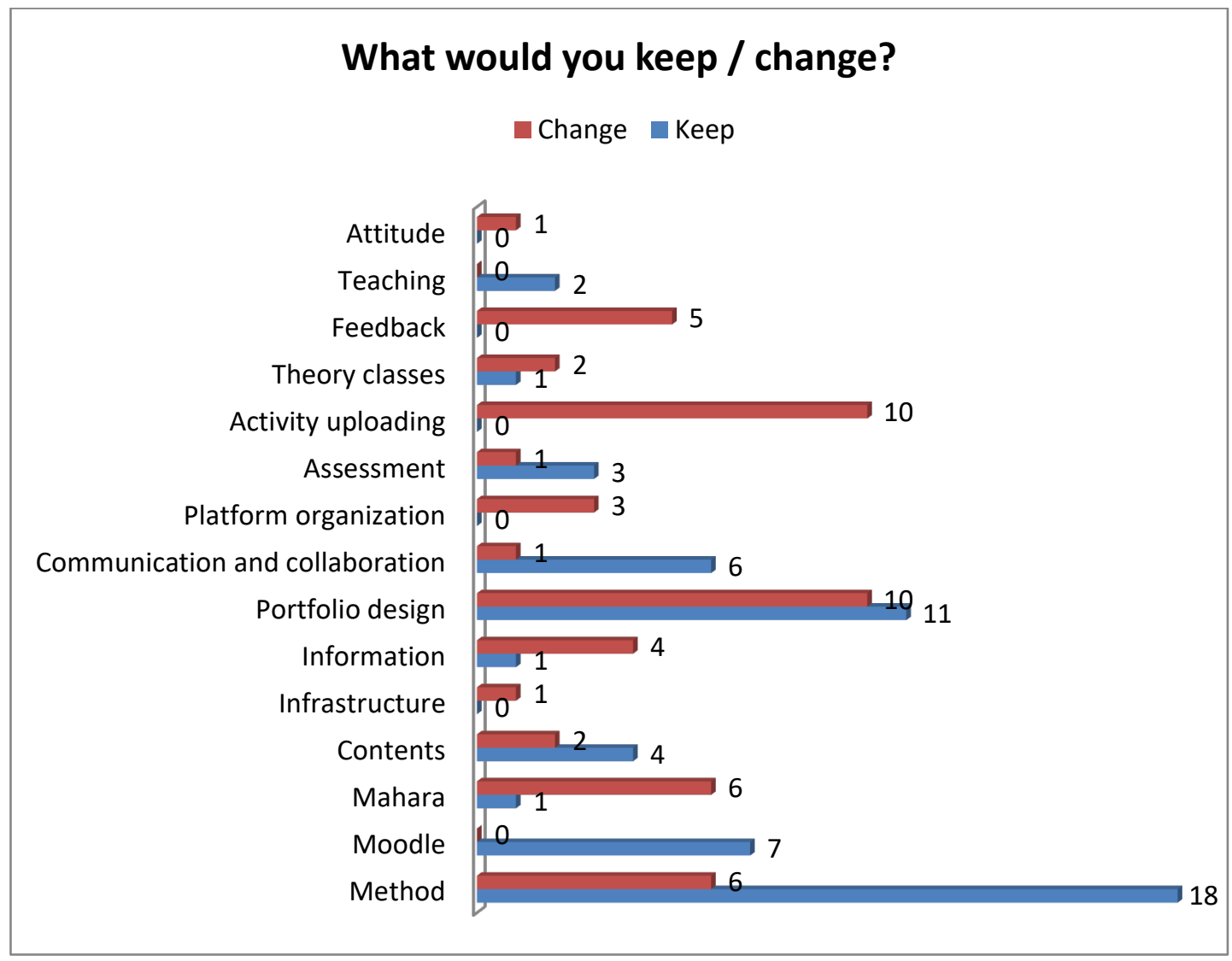

Figure 5. Content analysis: What would you keep/change in the platform? 
According to the results, most students would keep the general methodology (electronic portfolio, platforms...). They respond with statements such as, 'In general, I would keep the methodology used, and everything I learned seems appropriate and useful to me' (67\#), 'The use of the eportfolio and the exercises are good' (68\#) or 'I would keep the system of doing exercises and projects independently with the platform, which lets you organize your time' (38\#).

Second, the students would keep the portfolio design (11 thematic units categorized). Here, they mention the activities included in the portfolio, such as: 'I would also keep activities like the spot and creation of, for example, a blog, since these are fun activities and ones that involve the relationship between theory and practice' (\#9) or 'I would keep the portfolio project' (\#34). Ten comments express the desire to change some aspect of the portfolio design, such as 'The seminars should include the activities needed to train us in ICTs' (\#19) or 'I would replace the final project with a more specific project' (\#65).

Another category, on collaboration and communication, relates directly to the results obtained on the questionnaire (students evaluate the collaborative learning tools that this system provides very positively). Students state that 'Forums are really good, both to express our opinions and ideas on the topics proposed, and for questions and messages from the professor...' (\#99).

The evaluations of the platforms used (separately) show a clear preference for the Moodle platform, which 7 respondents would keep, over Mahara, which 6 would eliminate. In the students' opinion, one of the main problems with the Mahara platform is its procedure for uploading activities. The system used requires the student to develop the page to include in his/her portfolio in Mahara, which can then be sent from the Moodle platform. This twofold task seems to require more training, as can be inferred from some opinions, such as 'I would change the way of uploading activities to Mahara/Moodle, I think it is a little confusing' (\#27).Ten of the units categorized repeat this negative opinion on how to upload activities.

Another characteristic that the students would change and that is very important is the need for more feedback and monitoring of the projects developed through the portfolio. Five of the units categorized express this need, with comments like, '...but being able to have continuous assessment of my activities, to know what I have to improve or change, although this would mean more effort from the professors' (\#71). Monitoring and feedback on the work incorporated into the portfolio is a characteristic crucial to its success, but the high number of students per course often prevents the professors from performing this task effectively.

Based on the results discussed in this section and relative to the first hypothesis, the study confirms that, although students show a moderately favourable attitude to the motivation experienced with the study's methodological strategy, motivation is not the highest-scoring characteristic of the experience. Possibilities for participation and improving work autonomy seem to be the characteristics that the participants perceive most favourably.

\section{Differences between Degree Programmes}

To confirm whether there are differences between the three groups of students in degree of satisfaction with the electronic portfolio through Moodle-Mahara as a learning tool, an ANOVA analysis of one factor was performed. The goal was to detect differences in the students' opinions of the three dimensions of the questionnaire, but no significant differences were obtained at levels of either.005 or.001. Comparison of means shows some differences, especially in Dimension 1, which seeks to analyse students' opinion of the use of the platform as methodological tool (Figure $6)$. 


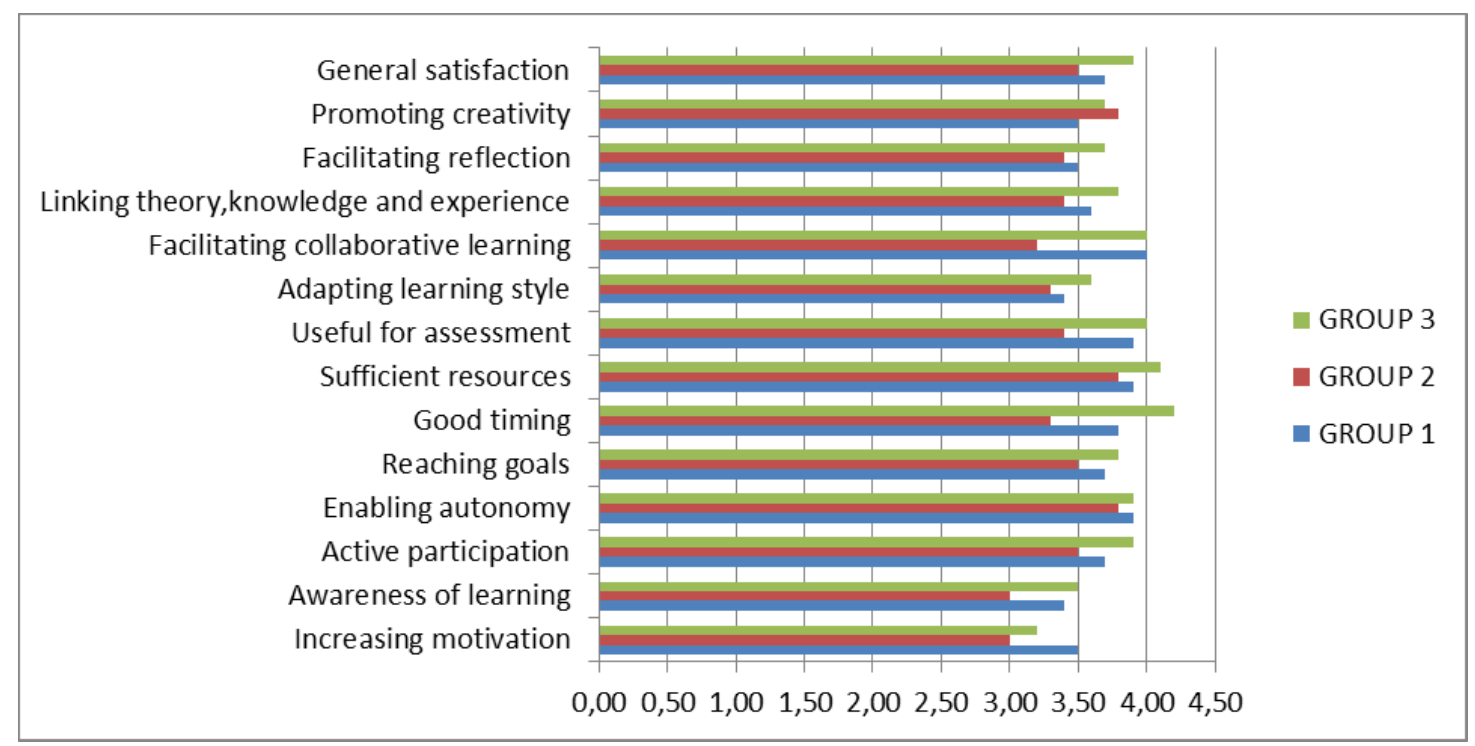

Figure 6. Distribution of means for different groups in Dimension 1 of the questionnaire: Electronic portfolio as a methodological strategy

The students from the group in Elementary Education (Group 1) express a stronger belief that using the Moodle-Mahara tool increased their motivation in the course. The other two degree programmes are traditionally more reluctant to use technology in their professional activity.

Students in the undergraduate degree programme in Social Education (Group 2) only perceive one category more positively: fostering creativity through methodological strategy.

Two categories are perceived equally by students in the Primary and Early Childhood programmes (Group 3): improving autonomy and fostering ability to work collaboratively.

In the other items, the Early Childhood Education group shows more agreement with the questionnaire statements.

\section{Impact of Participation on Performance}

This study also analyses the correlations to confirm whether more active student participation in the platform influenced the final grade in the subject. The results are shown in Table1.

Table 1. Correlation of grade in the subject with activity in the platform

\begin{tabular}{llll}
\hline & & GRADE & ACTIVITY \\
\hline GRADE & $\begin{array}{l}\text { Pearson correlation } \\
\text { Sig. (bilateral) }\end{array}$ & 1 & $.407^{* *}$ \\
& $\mathrm{~N}$ & 162 & .000 \\
ACTIVITY & Pearson correlation & $.407^{* *}$ & 152 \\
& Sig. (bilateral) & .000 & 1 \\
& $\mathrm{~N}$ & 152 & 152 \\
\hline
\end{tabular}

**. Significant correlation at level 0.01

The correlation between grade earned in the subject and activity on the platform (as defined in the methodology section) for the three groups indicates that platform participation influences the final grade in the subject and vice versa. The result obtained is 0.5 (bilateral sig. $=.000$ ), with a confi- 
dence level of $99 \%$. Students who participated more actively in the platform also obtained a higher final grade. The higher the grade in the subject, the greater the number of actions performed in the platform, that is, the greater the activity in the platform.

The results confirm that greater activity (more actions in the platform) permits the student to obtain a higher grade in the subject. Although many variables are involved, according to these data, more actions in the platform can contribute to obtaining a better grade in the subject.

According to these results, and in response to the third study hypothesis, the results affirm that students' active participation in the work environment designed through the Moodle-Mahara platform is indeed directly related to their performance in the course.

\section{Discussion}

According to the students' perceptions, despite their generally positive opinion of the methodological strategy used, the resources and tools ranked highest seem to be those that give greater autonomy in learning. These results follow the lines of other studies (Abrami et al., 2008; Galy, Downey, \& Johnson, 2011; Jafari \& Kaufman, 2006). In a study summarized by Jafari and Kaufman (2006), the goal of which was to assess digital competency development over a threemonth period and to examine pre-service teachers' perception of the electronic portfolio as a learning tool, the results show that pre-service teachers' technological competencies increased while they worked on the electronic portfolio and that they responded favourably to the electronic portfolio as a learning tool. This study also obtains this result.

A recent, systematic review performed at Maastricht University also shows perception of student autonomy to be one of the factors influenced by the use of e-portfolios (Beckers, Dolmans, \& van Merriënboer, 2016). Studies show that e-portfolios can be used to facilitate the development of competencies for self-directed learning. They identify the following variables that may influence this development: institutional factors, curricular factors, learning process factors, personal factors, and portfolio factors. Portfolios are used most effectively when faculty development aimed at supervising self-directed learning skill development is provided, when the portfolio is integrated into the educational routine, when teachers coach students regularly, and when scaffolding is applied to increase motivation, among other conditions. More systematic and regular training, as well as improvement in the quantity and quality of the feedback provided might have helped to produce a significant influence on motivation in this study, although there is no evidence for this conclusion.

The variable of gender in the student samples, which corresponds to the natural class groups (predominantly feminine), as well as the teacher-learning dynamic (the same professor in all groups) probably prevents finding significant differences in motivation that might be found in other studies.

In this kind of virtual environment in blended learning modes, the students primarily feel greater freedom to adapt the resources and their own learning strategies to their needs (Halverson et al., 2014; Kerres \& De Witt, 2003). It would be necessary to investigate this finding through case studies using qualitative methodologies, giving students the opportunity to comment on the eportfolios created, on the process, and also on the products they generated. In a similar study, the results showed that the students expressed positive opinions and achieved self-efficacy through the e-portfolio as a tool to manage their learning and assessment during a semester (especially after the second month of use). The expected impact on their learning was less significant, however. Nevertheless, the students emphasised that the e-portfolio was valuable as a personal developmental learning tool (López-Fernández \& Rodríguez-Illera, 2009). 
Students also evaluated positively the collaborative learning opportunities the platform provides, stressing among these the power of the communication and interaction tools. The results thus indicate that greater student autonomy and awareness of learning does not mean that students are isolated and work alone, but that they also need to establish social communication ties with their classmates to feel part of the virtual community.

Despite the foregoing, the students do not seem clearly to perceive that using this methodology increases motivation in their learning process. Their evaluation of this aspect is moderate as compared to other studies (Clark, Chow-Hoy, Herter, \& Moss, 2001; Del Valle Escudero, Carreto, \& García, 2011; Hartnell-Young et al., 2007). One possible explanation of this finding is that the students in this study perceive this system as increasing their workload relative to other courses. Another possible explanation is that they seem not to like the approach of submitting activities through the two platforms (creating pages in Mahara and handing in assignments on Moodle). The goal of using Mahara is to gain maximum benefit from its simple method of creating web pages with abundant multimedia and nonlinear resources. If one does not take advantage of this potential and only uses Mahara to upload documents, the tool loses much expressive and creative value. It may be this underuse that weakens students' motivation, since the tool then seems of little use to the students.

\section{Future Research}

One way of increasing students' motivation that could constitute a future line of research is use of badges or insignias and gamification techniques to motivate learning. Badges are symbolic insignias that the student receives for mastering a specific ability, knowledge, or task, or if he or she earns a diploma. Badges are then displayed so that other classmates can see them. Educational designers can use badges to encourage students to get involved and learn, for example, by focusing the goals, and providing students with tasks that are challenging and have clear standards, reaffirming achievements, etc. (Dickey, 2005).

As to participation, most students agree that the tool fosters their active participation in the subject (Gámiz et al., 2014). This opinion is registered in the questionnaire items and their responses to the open question, in which they mention the importance of tools such as forums to express their opinions and concerns. The study also shows this finding in establishing the relation between the students' activity in the platform and final grade in the course. The authors hope in future studies to test this result with a larger sample of groups that have used this methodology.

Another characteristic for future study, as demonstrated in the questionnaire responses and perceived in the authors' practical experience, is the students' request for more feedback on their electronic portfolio work. Since professor workload becomes too high when working with individual portfolios in large groups, the possibility of exploring design of group learning portfolios is proposed.

Another question that arises is whether significant differences exist in students' opinions by group and specialization. Analysis of the results showed no statistically significant differences, although variations do exist in the averages that would have to be analysed in greater depth. Another future line of study involves performing this comparison with different course contents to determine whether type of content could be a stronger factor establishing differences between groups.

\section{Conclusions}

This study describes and interprets the possibility of improving university teaching in blendedlearning environments, focusing on learning with e-portfolios. Although further, independent research is required on the factors associated with the increase in motivation, there is evidence 
that autonomous learning and participation are increased, from which the study affirms that the eportfolio is form of a technology-enhanced learning in university institutions (Price \& Kirkwood 2014), based on the students' perspectives of these variables.

The fact that the university students in this study are prospective teachers means that the effect of the use of e-portfolios can be expanded in learning in primary and secondary education once the experience in the university is projected into the field experiences.

This study has shown the impact of participation on performance through a descriptive, exploratory study design. The most promising direction in which to advance knowledge is to develop the study and analysis of students' digital competency in greater depth for professors, including the levels of engagement with electronic portfolios, as well as motivation, participation and autonomous learning.

\section{Acknowledgements}

This work was supported by University of Granada (Teaching innovation and best practices Program) and General Secretariat of Universities, Research and Technology (Ministry of Economy, Innovation, Science and Employment. Government of Andalusia, Spain. Strengthening Program 2015).

\section{References}

Abrami, P., \& Barrett, H. (2005). Directions for research and development on electronic portfolios. Canadian Journal of Learning and Technology, 31(3).

Abrami, P., Wade, A., Pillay, V., Aslan, O., Bures, E. M., \& Bentley, C. (2008). Encouraging self-regulated learning through electronic portfolios. Canadian Journal of Learning and Technology, 34(3).

Akçil, U., \& Arap, I. (2009).The opinions of education faculty students on learning processes involving eportfolios. Procedia - Social and Behavioral Sciences, 1(1), 395-400. doi:10.1016/j.sbspro.2009.01.071

Alexiou, A., \&Paraskeva, F. (2010). Enhancing self-regulated learning skills through the implementation of an e-portfolio tool. Procedia - Social and Behavioral Sciences, 2(2), 3048-3054. doi:10.1016/j.sbspro.2010.03.463

Bahous, R. (2008). The self-assessed portfolio: A case study. Assessment \& Evaluation in Higher Education, 33(4), 381-393. doi:10.1080/02602930701562866

Ballard, J., \& Butler, P. (2011).Personalised learning: Developing a Vygotskian framework for e-learning. International Journal of Technology, Knowledge and Society, 7(2), 21-36.

Barrett, H. C. (2007). Researching electronic portfolios and learner engagement: The REFLECT initiative. Journal of Adolescent and Adult Literacy, 50(6), 436-449. doi:10.1598/JAAL.50.6.2

Barrett, H. C. (2010). Balancing the two faces of eportfolios. Educação, Formação\&Tecnologias, 3(1), 614.

Barrett, H. C., \& Garrett, N. (2009). Online personal learning environments: Structuring electronic portfolios for lifelong and life-wide learning. On the Horizon, 17(2), 142-152. doi:10.1108/10748120910965511

Beckers, J., Dolmans, D.\& van Merriënboer, J. (2016). E-portfolios enhancing students' self-directed learning: A systematic review of influencing factors. Australasian Journal of Educational Technology, $32(2)$.

Blackburn, J. L., \& Hakel, M. D. (2006). Enhancing self-regulation and goal orientation with ePortfolios. In A. Jafari \& C. Kaufman, Handbook of research on eportfolios (pp.83-89). London: Idea Group. 
Impact of E-Portfolios in Higher Education

Blau, I., Mor, N., \&Neuthal, T. (2013). Interacting for learning: Digital portfolios for a learning community in a university course. Learning, Media and Technology, 38(3), 241-255. doi:10.1080/17439884.2012.709864

Boulton, H. (2014). ePortfolios beyond pre-service teacher education: A new dawn? European Journal of Teacher Education, 37(3), 374-89. doi:10.1080/02619768.2013.870994

Butler, P. (2006.) A review of the literature on portfolios and electronic portfolios. Palmerston North, New Zealand: Massey University College of Education.

Cambridge, B. L. (2001). Electronic portfolios as knowledge builders. In B. L. Cambridge, S. Kahn, D.P. Tompkins, \& K. B. Yancey, Electronic portfolios: Emerging practices in student, faculty and institutional learning (pp.1-11). Washington, DC: American Association for Higher Education.

Cambridge, D., Cambridge, B. L., \& Yancey, K. (2009).Electronic portfolios 2.0: Emergent research on implementation and impact. Sterling, Virginia: Stylus Publishing.

Clark, C., Chow-Hoy, T., Herter, R., \&Moss, P. (2001). Portfolios as sites of learning: Reconceptualizing the connections to motivation and engagement. Journal of Literacy Research, 33(2), 211-241. doi:10.1080/10862960109548110

Chang, C. C., Liang, C., Tseng, K. H., \& Tseng, J. S. (2014). Using e-portfolios to elevate knowledge amassment among university students. Computers\& Education, 72, 187-195. doi:10.1016/j.compedu.2013.10.015

Chang, C. C., Tseng, K. H., Liang, C., \& Chen, T.Y. (2013). Using e-portfolios to facilitate university students' knowledge management performance: E-portfolio vs. non-portfolio. Computers \&Education, 69, 216-224. doi:10.1016/j.compedu.2013.07.017

Chen, M. Y., Chang, F. M. T., Chen, C. C., Huang, M. J., \& Chen, J. W. (2012). Why do individuals use eportfolios? Educational Technology \& Society, 15(4), 114-125.

Cheng, G., \&Chau, J. (2013). A study of the effects of goal orientation on the reflective ability of electronic portfolio users. Internet and Higher Education, 16, 51-56. doi:10.1016/j.iheduc.2012.01.003

Colás, M. P., \& Buendía, L. (1998). Investigación Educativa. Seville, Spain: Alfar.

Del Valle Escudero, P., Carreto, M. C. M., \& García, A. S. (2011). Motivación y autorregulación a partir del uso del portafolio electrónico en los alumnos del nivel superior [Motivation and self-regulation in the use of digital portfolio of students in higher education]. Revista Ibero-Americana de Educação, 55, 173-187.

Dickey, M. (2005). Engaging by design: How engagement strategies in popular computer and video games can inform instructional design. Educational Technology Research and Development, 53(2), 67-83. doi:10.1007/BF02504866

Fox, D. (1987). El proceso de investigación en educación [The research process in education]. Pamplona: EUNSA.

Galy, E., Downey, C., \& Johnson, J. (2011).The effect of using e-learning tools in online and campus-based classrooms on student performance. Journal of Information Technology Education: Research, 10(1), 209-230. Retrieved from http://www.informingscience.org/Publications/1503

Gámiz, V., Montes, R., \& Pérez, M. C. (2014). Self-assessment via a blended-learning strategy to improve performance in an accounting subject. RUSC. Universities and Knowledge Society Journal (RUSC), 11(2), 41-54. doi:10.7238/rusc.v11i2.2055

Gorbunovs, A., Kapenieks, A., \&Kudina, I. (2013).Competence development in a combined assessment and collaborative e-portfolio information system. Procedia Computer Science, 26, 79-100. doi:10.1016/j.procs.2013.12.009

Graham, C. (2006). Blended learning systems: Definitions, current trends and future directions. In C. Bonk \& C. Graham, The handbook of blended learning (pp. 3-21). San Francisco: Pfeiffer. 
Halverson, L., Graham, C., Spring, K., Drysdale, J., \& Henrie, C. (2014). A thematic analysis of the most highly cited scholarship in the first decade of blended learning research. The Internet and Higher Education, 20, 20-34. doi:10.1016/j.iheduc.2013.09.004

Hartnell-Young, E., Harrison, C., Crook, C., Pemberton, R., Joyes, G., Fisher, T., \& Davies, L. (2007). Impact study of e-portfolios on learning. British Educational Communications and Technology Agency (BECTA), 1, 1-17.

Hartnell-Young, E., \&Morriss, M. (2007). Digital portfolios: Powerful tools for promoting professional growth and reflection. Thousand Oaks, CA: Corwin Press.

Jafari, A., \& Kaufman, C. (2006). Handbook of research on eportfolios. Hershey, PA: IGI Global.

Jeffrey, L., Hegarty, B., Kelly, O., Penman, M., Coburn, D., \& McDonald, J. (2011). Developing digital information literacy in higher education: Obstacles and supports. Journal of Information Technology Education: Research, 10(1), 383-413. Retrieved from http://www.informingscience.org/Publications/1532

Kerres, M., \&De Witt, C. (2003). A didactical framework for the design of blended learning arrangements. Journal of Educational Media, 28(2-3), 101-113. doi:10.1080/1358165032000165653

López-Fernández, O., \& Rodríguez-Illera, J. L. (2009). Investigating university students' adaptation to a digital learner course portfolio. Computers \&Education, 52(3), 608-616. doi:10.1016/j.compedu.2008.11.003

Ntuli, E., Keengwe, J., \& Kyei-Blankson, L. (2009). Electronic portfolios in teacher education: A case study of early childhood teacher candidates. Early Childhood Education Journal, 37(2), 121-126. doi:10.1007/s10643-009-0327-y

Pollard, C., \& Pollard, R. (2004). Research priorities in educational technology: A Delphi study. Journal of Research on Technology in Education, 37(2), 145-160. doi:10.1080/15391523.2004.10782430

Price, L., \& Kirkwood, A. (2014). Using technology for teaching and learning in higher education: A critical review of the role of evidence in informing practice. Higher Education Research and Development, 33(3), 549-564. doi:10.1080/07294360.2013.841643

Ramakrisnan, P., Yahya, Y. B., Hasrol, M. H., \&Aziz, A. A. (2012). Blended learning: A suitable framework for e-learning in higher education. Procedia - Social and Behavioral Sciences, 67, 513-526. doi:10.1016/j.sbspro.2012.11.356

Ritzhaupt, A., Parker, M., \& Ndoye, A. (2012). Eportfolio integration in teacher education programs: Does context matter from a student perspective? In D. Polly, C. Mims, \& K. A. Persichitte, Developing technology-rich teacher education programs: Key issues (pp.250-264). Hershey, PA: IGI Global. doi:10.4018/978-1-4666-0014-0.ch017

Smith, J. J. \& Greene, H.C. (2013). Pre-service teachers use e-learning technologies to enhance their learning. Journal of Information Technology Education: Research, 12(1), 121-140. Retrieved from http://www.informingscience.org/Publications/1790

Spendlove, D., \& Hopper, M. (2006). Using 'electronic portfolios' to challenge current orthodoxies in the presentation of an initial teacher training design and technology activity. International Journal of Technology and Design Education, 16(2), 177-191. doi:10.1007/s10798-005-3596-9

Tochon, F. V. (2012). Emerging technologies in educational institutions: Assets and potential risks. Journal for Educators, Teachers and Trainers, 3, 188-202.

Tosh, D., Light, T., Fleming, K., \&Haywood, J. (2005). Engagement with electronic portfolios: Challenges from the student perspective. Canadian Journal of Learning and Technology, 31(3).

Trent, J., \&Shroff, R. H. (2013). Technology, identity, and community: The role of electronic teaching portfolios in becoming a teacher. Technology Pedagogy and Education, 22(1), 3-20. doi:10.1080/1475939X.2012.720416 
Von Konsky, B., \& Oliver, B. (2012).The iportfolio: Measuring uptake and effective use of an institutional electronic portfolio in higher education. Australasian Journal of Educational Technology, 28(1), 6790 .

Wakimoto, D., \& Lewis, R. (2014). Graduate student perceptions of eportfolios: Uses for reflection, development, and assessment. The Internet and Higher Education, 21, 53-58. doi:10.1016/j.iheduc.2014.01.002

Wang, L. (2010). Integrating communities of practice in e-portfolio assessment: Effects and experiences of mutual assessment in an online course. Internet and Higher Education, 13(4), 267-271. doi:10.1016/j.iheduc.2010.07.002

Wray, S. (2007). Teaching portfolios, community, and pre-service teachers' professional development. Teaching and Teacher Education, 23(7), 1139-1152. doi:10.1016/j.tate.2006.10.004

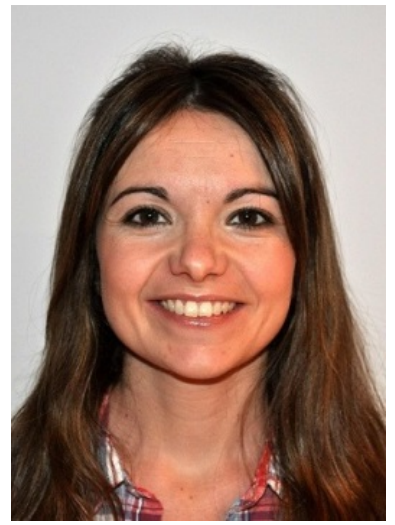

\section{Biographies}

Vanesa-María Gámiz-Sánchez is a Computer Science Engineer and holds a PhD in Pedagogy from the University of Granada. Since 2010, she has taught in the Department of Pedagogy and School Organization in the Faculty of Education, where she previously worked as a Doctoral Fellow in Training of Research Professionals. Her lines of research are oriented to e-learning and the use of Information and Communication Technologies in education, especially in Higher Education. She has participated as a member in various teaching innovation projects and (2012-2014) coordinated the project entitled "The e-portfolio as pedagogical strategy for learning and evaluation. Implementation using Mahara integrated with Moodle". She has also been a research team member of various European projects on e-learning (OERTEST, DARE+, ARMAZEG) and has served as a teacher in various training activities in new technologies for university faculty.

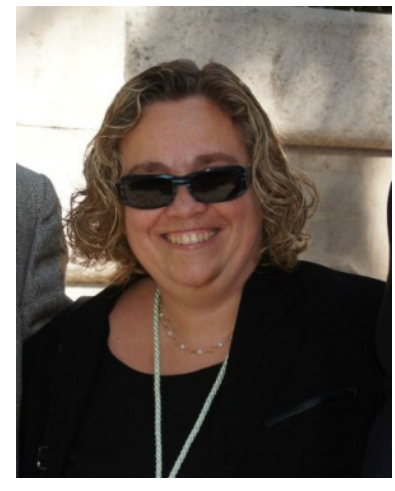

María-Jesús Gallego-Arrufat received her Ph.D.in Education in 1993 from the University of Granada, Spain. She is Professor of Education \& Educational Research in the Faculty of Education of University of Granada. Her specialization (by UNESCO code) is: 1203.10 (Computer-Aided Teaching) - 5803.02 (Teacher Training). She is a researcher on Information and Communication Technology (ICT) in Education and Teacher Education. Her main lines of research are Educational Technology - Teacher Education - Higher Education, specifically the practicum, professional development and school leadership training in virtual environments. She is Director of the Master's and Doctoral Programme "Curriculum and Teacher Training", and Director of the Journal for Educators, Teachers and Trainers (JETT) ISSN 1989 - 9572. Her publications can be viewed on: Google Scholar v7oWURQAAAAJ\&hl. 


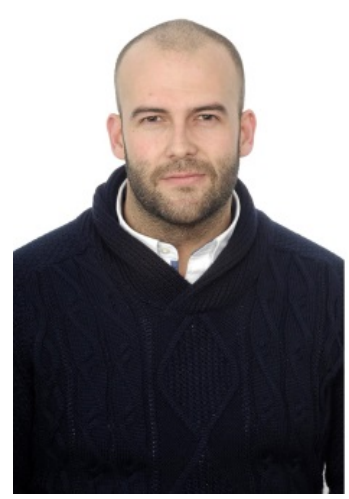

Emilio Crisol-Moya received his Bachelor's Degree in Pedagogy from the University of Granada in 2005 and an International $\mathrm{PhD}$ in Education from the same university in 2012. He is currently Assistant Professor in the Department of Pedagogy and School Organization of the Faculty of Education at the University of Granada. His lines of research are innovation; pedagogical methodology, curriculum and training; and school speech therapy and Special Education, among others. 